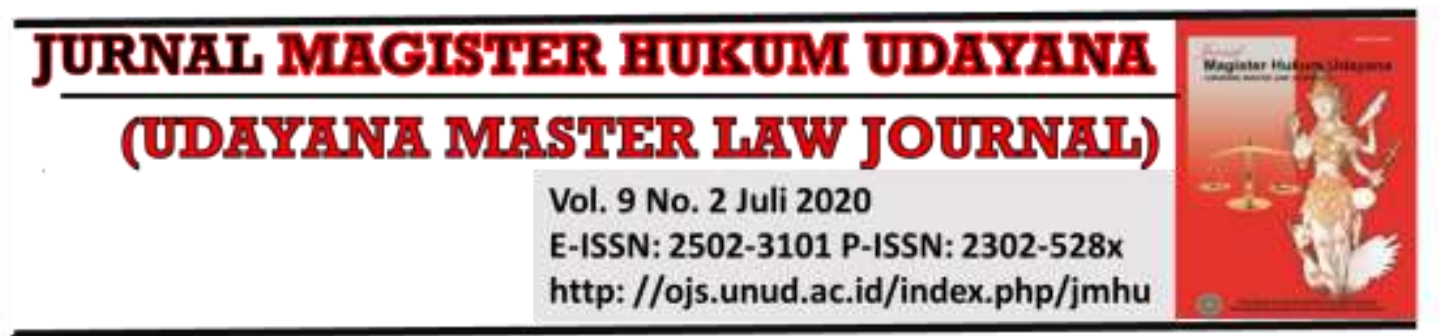

\title{
Menerobos Prinsip Kerahasiaan Bank Guna Mencegah Risiko Gagal Bayar dan Kejahatan Lintas Negara Menggunakan Letter of Credit
}

\author{
Diah Rahma Kusumaningrum¹, Pujiyono²
}

${ }^{1}$ Fakultas Hukum Universitas Sebelas Maret, E-mail: diahrk@student.uns.ac.id ${ }^{2}$ Fakultas Hukum Universitas Sebelas Maret, E-mail: pujifhuns@gmail.com

\begin{tabular}{l}
\hline Info Artikel \\
\hline Masuk: 20 Maret 2020 \\
Diterima: 1 Mei 2020 \\
Terbit: 32 Juli 2020 \\
Keywords: \\
Letters of Credit; Bank; \\
International Trades; \\
Prudential Banking Principle \\
\\
\\
\\
Corresponding Author: \\
Diah Rahma Kusumaningrum, \\
Email: \\
diahrk@student.uns.ac.id \\
DOI: \\
10.24843/JMHU.2020.v09.i02. \\
Prinsip Kehati-hatian Bank \\
Letter of Credit, Bank, \\
\end{tabular}

\begin{abstract}
L/C is a means of payment for international trades which, to date, is considered to have a high level of security due to the sharing of risks for the parties involved. What distinguishes the L/C payment method is the involvement of banks as "third parties" outside the Sales Contract, acting as the risk "guarantor". However, even though it is considered as the safest payment method, there are still risks lurking. Fraudulent practices can still be carried out by irresponsible persons by exploiting loopholes of $\mathrm{L} / \mathrm{C}$ mechanism. This study aims to find alternatives to overcome and prevent this from happening thus prevent the Bank and related parties from losses, both materially and immaterially. Normative juridical research methods are used because the focus of this study departs from the vagueness of the norm. The statutory approach and analytical approach applied by analyzing legal norms in statutory regulations. The technique of tracing legal materials uses document study techniques and using qualitative analysis of law books, UCP, legal journals, and regulations. This study indicates that Bank can maximize its authority through the Prudential Banking Principle to "breakthrough" the Principles of Confidentiality to share information about importers' financial track records as an effort to strengthen due diligence thus implementing Prudential Banking. The legal instruments in Indonesia used to exercise this mechanismas are Banking Law article 44 and PBI 19 of 2017 article 56 paragraph (1) and (2).

\begin{tabular}{l} 
Abstrak \\
\hline L/C merupakan sarana pembayaran transaksi perdagangan \\
internasional yang sampai saat ini dianggap memiliki tingkat \\
keamanan yang tinggi karena adanya pembagian risiko bagi para \\
pihak yang terlibat. Hal yang membedakan metode pembayaran \\
L/C dengan yang lain adalah keterlibatan bank sebagai "pihak \\
ketiga" di luar perjanjian jual beli yang menjadi penjamin risiko. \\
Namun, meskipun dianggap sebagai metode pembayaran yang \\
paling aman, masih ada risiko yang mengintai bagi Bank. \\
Praktik-praktik kecurangan masih saja dapat dilakukan oleh \\
oknum dengan memanfaatkan celah dari mekanisme penggunaan \\
L/C. Penelitian ini bertujuan untuk mencari alternatif guna \\
menanggulangi dan mencegah terjadinya hal tersebut sehingga
\end{tabular}
\end{abstract}


p.09

\section{Pendahuluan}

Mencermati perkembangan zaman yang terus berubah, kebutuhan manusia semakin lama semakin beragam jenisnya, di sisi lain, keberadaan sumber daya dan kemampuan produksi yang dimiliki oleh setiap negara memiliki ciri khas masing-masing. Beberapa negara unggul terkait produksi makanan pokok sumber karbohidrat yang melimpah, ada negara yang mampu melatih dan menghasilkan sumber daya manusia yang terampil, ada negara yang unggul dalam pengembangan teknologi, dan berbagai keunggulan lainnya. Pada saat yang bersamaan, ketika negara memiliki keunggulan atas suatu bidang terdapat pula aspek di mana ia lemah dalam kepemilikan sumber daya tertentu yang lain. Inilah titik yang menjembatani pentingnya hubungan internasional yang untuk selanjutnya melahirkan hubungan perdagangan lintas negara, yang dalam penulisan ini Penulis istilahkan dengan "Perdagangan Internasional," guna memenuhi berbagai kebutuhan masyarakat di seluruh dunia.

Perdagangan Internasional, melalui ekspor-impor, selain berfungsi sebagai sarana pemenuhan kebutuhan pokok individu juga membawa pengaruh dalam perekonomian, hubungan hukum, dan hubungan diplomatik antar negara. Kepentingan para pihak yang terkait dalam suatu perdagangan internasional tentu saja memerlukan suatu jaminan perlindungan guna menumbuhkan rasa percaya (trust) untuk memperlancar interaksi yang dilakukan. Salah satu permasalahan yang cukup sensitif dalam suatu hubungan perdagangan adalah mekanisme pembayaran. Terlebih karena dalam perdagangan internasional ada jarak yang memisahkan ditambah lagi perbedaan yurisdiksi yang dapat berpengaruh terhadap pelaksanaan transaksi.

Berbagai metode pembayaran kemudian diperkenalkan sebagai pilihan untuk memberikan rasa perlindungan atas keamanan transaksi yang kemudian dapat disesuaikan dengan kebutuhan para pihak. Secara umum, penjual (eksportir) dan pembeli (importir) dapat memilih salah satu diantara empat metode pembayaran dalam transaksi perdagangan internasional. Diurutkan berdasarkan keuntungannya, 
dari metode yang paling menguntungkan penjual hingga yang paling menguntungkan pembeli, pilihan tersebut mencakup prepayment (pembayaran di muka), pembayaran dengan Letter of Credit, pembayaran dengan penyerahan dokumen, dan Open Account. ${ }^{1}$ Melalui Peraturan Bank Indonesia telah diatur bahwa, di Indonesia, pembayaran transaksi impor dapat dilakukan dengan Letter of Credit, Inkaso (Collection), Advance Payment, Open Account, Konsinyasi (Consignment), serta cara pembayaran lainnya yang umum dalam perdagangan internasional sepanjang disepakati oleh para pihak. ${ }^{2}$ Tulisan ini akan membahas metode Letter of Credit (dalam tulisan lain disebut juga dengan Letters of Credit atau Document of Letters of Credit).

Letter of Credit (untuk selanjutnya dalam tulisan ini akan lebih banyak disebut dengan "L/C") pada prinsipnya merupakan dokumen yang dikeluarkan oleh bank (maka bank tersebut berperan sebagai Opening Bank alias Issuing Bank dan umumnya adalah bank yang bertempat sesuai dengan domisili negara Applicant) atas permintaan dari importir (dalam hal ini bertindak sebagai Applicant) untuk kepentingan transaksinya terhadap eksportir (dalam hal ini eksportir menjadi pihak yang memperoleh manfaat atau Beneficiary). Catatan dalam pengertian ini, bank yang berpartisipasi dalam suatu L/C selain Issuing Bank (sebagai pihak Bank yang utama), ada pula opsi untuk menunjuk Advising Bank, Negotiating Bank, dan Confirming Bank dengan maksud untuk mempermudah hubungan dengan Beneficiary yang biasanya terpaut jarak lintas negara dengan Applicant. Terhadap pertimbangan tersebut maka dalam penulisan ini, istilah Bank dapat mengacu pada Advising Bank, Issuing Bank, Confirming Bank dan Negotiating Bank dalam perannya sebagai pihak ketiga dalam L/C, kecuali dituliskan secara jelas.

L/C dapat digunakan sebagai sarana pembayaran baik untuk transaksi lokal maupun lintas negara ${ }^{3}$ (transaksi perdagangan internasional) yang, sampai saat ini, dianggap memiliki tingkat keamanan yang paling tinggi karena adanya pembagian risiko yang seimbang bagi para pihak yang terlibat. Hal yang membedakan metode pembayaran $\mathrm{L} / \mathrm{C}$ dengan yang lain adalah diperlukannya keterlibatan bank (atau beberapa bank) sebagai "pihak ketiga" di luar perjanjian jual beli (perjanjian ini dikenal juga dengan istilah Sales Contract) yang menjadi penjamin risiko. Ketika penjual dan pembeli (eksportir dan importir) menemui terlalu banyak rintangan untuk mencapai kesepahaman, para pihak biasanya meminta Bank untuk memangku tanggung jawab. ${ }^{4}$ Namun, meskipun dianggap sebagai metode pembayaran yang paling aman, masih ada risiko yang mengintai, baik terhadap Applicant, Beneficiary, ataupun Bank. Ada dua prinsip yang penting dalam L/C, yaitu Doktrin Otonomi (the Doctrine of Autonomy) 5 atau dalam banyak tulisan dikenal juga sebagai Prinsip Independensi (Principle of Independence) (dalam penulisan ini yang digunakan adalah istilah Principle of

\footnotetext{
${ }^{1}$ Mann, R.J. (2000). The Role of Letters of Credit in Payment Transactions. Michigan Law Review, 98(8): 2494-2536. DOI: 10.2307/1290352, h. 2516.

2 Peraturan Bank Indonesia No. 5/11/PBI/2003 Tentang Pembayaran Transaksi Impor (Lembaran Negara Tahun 2003 No. 71 DLN), Pasal 8 Ayat (1).

${ }^{3}$ CheHashim, R., \& Mahdzan, N.S. (2014). Fraud in Letter of Credit Transactions: The Experience of Malaysian Bankers. International Journal of Law, Crime and Justice, 42(3): 224-236. DOI: https:// doi.org/10.1016/j.ijlcj.2014.01.008, h. 225.

${ }^{4}$ Garcia, R.L.F. (2010). The Autonomy Principle of Letters of Credit. Mexican Law Review, 3(1): 67-96. DOI: http://dx.doi.org/10.22201/iij.24485306e.2010.5, h. 71.

${ }^{5}$ Buckley, R.P., \& Gao, X. (2002). The Development of The Fraud Rule in Letter of Credit Law: The Journey So Far and the Road Ahead. University of Pennsylvania Journal of International Law, 23(4): 663-712. Retrieved from https://scholarship.law.upenn.edu/jil/vol23/iss4/2, h. 663.
} 
Independence atau Independence Principle) dan Prinsip Kepatuhan Ketat (Principle of Strict Compliance). ${ }^{6}$ Namun demikian masih ada juga pelaku usaha yang enggan menggunakan L/C dalam transaksi yang dilakukannya. Hal ini, antara lain disebabkan karena dalam mekanisme L/C tidak ada jaminan bahwa barang yang diterima sesuai dengan barang yang dipesan, sebagai akibat dari adanya Principle of Independence (ketentuan mengenai Principle of Independence akan dijelaskan tersendiri); selain itu adanya kebiasaan dari sisi para pihak, pelaku usaha yang telah lama berkecimpung dalam perdagangan internasional, yang telah memiliki rasa percaya dengan mitranya sehingga memilih untuk hanya menggunakan payment agreement documents daripada menggunakan $\mathrm{L} / \mathrm{C}$, dengan pertimbangan untuk mengurangi biaya tambahan yang dapat timbul dari penggunaan L/C. Praktik-praktik kecurangan masih saja dapat terjadi, ketika celah dari mekanisme penggunaan L/C dimanfaatkan oleh oknumoknum tertentu dalam proses jual beli.

Risiko kerugian Applicant dapat terjadi dalam hal eksportir mengirimkan barang yang ternyata, setelah diterima, tidak sesuai ekspektasi atau dianggap tidak sesuai dengan sales contract. Dikatakan demikian karena pembayaran harus tetap dilaksanakan oleh Applicant sepanjang Bank telah menerima dokumen Bill of Lading yang diserahkan Beneficiary sebagai bukti bahwa Beneficiary telah melaksanakan kewajibannya sebagai eksportir berupa pengiriman barang kepada Applicant. Ini adalah salah satu konsekuensi dari Principle of Independence sebagaimana yang tertulis pada Pasal 5 UCP600 (Uniform Customs \& Practice for Documentary Credits) ${ }^{7}$ yang menyatakan bahwa Bank berurusan dengan dokumen; bukan dengan barang, jasa, maupun pelaksanaan di mana hal-hal yang berkaitan mungkin terjadi terhadap atau atas dokumen-dokumen tersebut [Bank deal with documents and not with goods, services or performance to which the documents may relate]. ${ }^{8}$ Prinsip bahwa pemeriksaan L/C bersifat "based on documents," secara tegas ${ }^{9}$ menyebabkan pertimbangan yang diambil oleh Bank untuk meloloskan L/C semata-mata hanya berdasarkan pada pemeriksaan dokumen saja, hal ini berimplikasi pada tidak dipertimbangkannya kondisi barang secara nyata atau secara fisik, dan dengan demikian memunculkan adanya celah lolosnya transaksi berisiko sepanjang dokumen yang diberikan sinkron dengan syarat-syarat yang tercantum pada L/C.

Risiko yang mengintai Beneficiary dapat berupa praktik manipulasi yang dilakukan dengan memanfaatkan Strict Compliance Principle guna mempersulit eksportir sebagai Beneficiary untuk mencairkan dana L/C dari Bank. Pasal 2 dalam UCP 600 dalam salah satu paragrafnya mendefinisikan penyampaian (presentation) yang sesuai sebagai penyampaian yang memenuhi kesesuaian syarat serta kondisi kredit, ketentuan-

\footnotetext{
${ }^{6}$ Zhang, Y. (2011). Approaches to Resolving the International Documentary Letters of Credit Fraud Issue. University of Eastern Finland.

7 UCP atau Uniform Customs \& Practice for Documentary Credits adalah perangkat aturan yang disepakati oleh Kamar Dagang Internasional (International Chamber of Commerce disingkat ICC) yang berlaku untuk lembaga keuangan yang menerbitkan L/C. UCP pertama dibuat pada tahun 1933 dan telah direvisi oleh ICC hingga sampai pada UCP600. UCP600 menggantikan UCP500 pada 1 Juli 2007.

8 Pasal 5 UCP600.

${ }_{9}^{9}$ Botosh, H. (2016). Evaluation of The Conditional-Absolute Payment Issue in Letters of Credit: Identifying Which Position Provides Maximum Party Autonomy, Certainty, Flexibility, Fairness and Good Faith. International Journal of Business, Economics and Law, 10(5): 9-14. ISSN: 2289-1552, h. 10.
} 
ketentuan UCP yang berlaku, dan praktik perbankan internasional [complying presentation means a presentation that is accordance with the term and conditions of the credit, the applicable provisions of the rules and international standard banking practice]. ${ }^{10}$ Dokumen yang diberikan haruslah selaras dengan syarat dan ketentuan dari L/C. Berdasarkan perjanjian antara Applicant dan Bank, Bank berkewajiban untuk mencermati batasan dari ketentuan-ketentuan yang diberikan dan memenuhinya berdasarkan Strict Compliance Principle. Ketika Applicant mengajukan permohonan L/C pada Issuing Bank tanpa melakukan kepatuhan ketat terhadap sales contract dengan berbagai alasan, hal ini dapat mempersulit pihak eksportir bahkan dapat mengakibatkan kerugian bagi eksportir. Beberapa modus yang digunakan antara lain tindakan menunda-nunda permohonan L/C oleh Applicant pada Issuing Bank; dan terjadinya diskrepansi atau ketidakcocokan, yaitu kesalahan-kesalahan penulisan seperti data identitas Beneficiary, tanggal tenggang waktu pengiriman, lokasi pengkapalan, dan sebagainya. Kesalahan seperti ini berpengaruh langsung pada dokumen yang harus diserahkan dan dalam banyak peristiwa menjadi dasar penolakan (rejection) terhadap pembayaran oleh Bank.

Selain itu, "L/C bodong" juga dapat mengakibatkan kerugian bagi Beneficiary. Jika importir menggunakan L/C bodong, atau mencuri formulir kosong L/C dari bank, atau mendapatkan kredit dari oknum pegawai bank yang bangkrut atau akan bangkrut, eksportir akan menghadapi risiko kehilangan barang yang telah dikirim beserta hak ekonomi yang semestinya didapatkan. Seperti kasus yang terjadi di sebuah perusahaan perdagangan di Cina tepatnya di Provinsi HeNan. Perusahaan tersebut menerima dokumen kredit dari sebuah bank Inggris bernama Standard Chartered Bank tepatnya di cabang Birmingham. Besaran kreditnya adalah USD 37,200,000 dan Advising Banknya adalah National Westminster bank di London. Berdasarkan konvensi internasional, Advising Bank semestinya adalah bank setempat (lokal) sesuai negara Beneficiary (dalam kasus ini semestinya Advising Banknya adalah bank Cina). Karena Advising Bank dari kredit tersebut bukanlah bank lokal dari kedudukan Beneficiary, sulit untuk memastikan keaslian kredit tersebut. Setelah dilakukan pemeriksaan oleh bank lokal Cina terhadap kredit tersebut, ditemukan beberapa kejanggalan: (1) formulir L/C tidak diberi tanggal, tidak ada alamat pengirim barang di muka amplop, dan alamat pos tidak dapat dikenali karena cap surat yang ambigu; (2) dokumen L/C menunjuk Advising Bank, National Westminster Bank, sebagai Negotiating Bank, yang mana merupakan suatu penyimpangan; (3) alamat dari Accepting Bank tidak dapat ditemukan dalam "buku tahunan bank"; (4) kepentingan dari kredit dituliskan dalam huruf cetak, bukan dengan tulisan tangan sehingga tidak dapat diidentifikasi; (5) barang diwajibkan untuk diangkut melalui udara ke Nigeria, yang mana merupakan modus yang selalu terjadi dalam kasus penipuan kredit. Berdasarkan poin-poin yang ditemukan, $\mathrm{L} / \mathrm{C}$ tersebut diidentifikasikan sebagai $\mathrm{L} / \mathrm{C}$ bodong secara kasat mata. ${ }^{11}$

Untuk risiko pada pihak Bank, dengan memperhatikan keberadaan prinsip dasar dari L/C yaitu Strict Compliance atas dokumen (yaitu dokumen sales contract) terhadap kredit (dokumen L/C), terletak pada pemeriksaan dokumen yang kemudian dapat

10 Pasal 2 UCP600.

${ }^{11}$ Kasus pada suatu bank di Cina yang didapat dari narasumber (seorang pegawai bank Cina yang bekerja di cabang Peking) dalam Yan, H. \& Xiao, L. (2013). Risk Analysis of Letter of Credit: Based on Principles of 'Independence' and 'Strict Compliance'. International Journal of Business and Social Science, 4(9): 199-209. Diambil dari https://ijbssnet.com/journals/Vol_4_No_9_August_2013/20.pdf, h.204. 
kita rujuk sebagai juga risiko utama bagi Bank. Pengadilan Inggris mengembangkan pernyataan tentang Strict Compliance pada tahun 1927. Prinsip Strict Compliance sebelumnya juga diatur dalam Pasal 13 UCP 500, dengan memberikan standar pemeriksaan dokumen dimana Bank patut melihat dengan teliti untuk mengetahui keadaan dari berbagai dokumen yang tercantum dalam Kredit secara hati-hati, guna menentukan muncul atau tidaknya, di hadapan mereka (sebagaimana yang terlihat), untuk memenuhi persyaratan dan ketentuan Kredit. Kepatuhan terhadap dokumen yang ditetapkan atas syarat dan ketentuan Kredit akan ditentukan oleh parameter praktik perbankan internasional. Bila dokumen tampak tidak konsisten satu sama lain maka dokumen tersebut dianggap 'tidak tampak sesuai' terhadap syarat serta ketentuan Kredit. Dokumen yang tidak diatur dalam Kredit tidak akan diperiksa oleh bank. Jika Bank menerima dokumen semacam itu maka Bank harus mengembalikannya pada pihak pemberi (presenter) atau melimpahkannya tanpa tanggung jawab [Banks must examine all documents stipulated in the Credit with reasonable care, to ascertain whether or not they appear, on their face, to be in compliance with the terms and conditions of the Credit. Compliance of the stipulated documents on their face with the terms and conditions of the Credit shall be determined by international standard banking practice as reflected in these Articles. Documents which appear on their face to be inconsistent with one another will be considered as not appearing on their face to be in compliance with the terms and conditions of the Credit. Documents not stipulated in the Credit will not be examined by banks. If they receive such documents, they shall return them to the presenter or pass them on without responsibility], ${ }^{12}$ yang selanjutnya semakin ditegaskan dengan Pasal 15 UCP 500 yang menyatakan bahwa Bank tidak bertanggung jawab atau berkewajiban atas bentuk, kecukupan, keakuratan, ketulenan, manipulasi, atau efek legal dari dokumen apa pun, atau untuk kondisi umum maupun khusus yang ditetapkan pada dokumen atau ditumpangkan di atasnya; mereka pun tidak bertanggung jawab atau memikul beban pertanggungjawaban untuk deskripsi, kuantitas, masa, kualitas, kondisi, packing, pengiriman, nilai ataupun keberadaan barang yang diwakili oleh dokumen, atau atas itikad baik serta tindakan dan/atau kecerobohan, solvabilitas, kinerja atau kedudukan pengirim, pembawa, pengirim, penerima atau penanggung barang, atau orang lain siapa pun [Banks assume no liability or responsibility for the form, sufficiency, accuracy, genuineness, falsification or legal effect of any document(s), or for the general and/or particular conditions stipulated in the document(s) or superimposed thereon; nor do they assume any liability or responsibility for the description, quantity, weight, quality, condition, packing, delivery, value or existence of the goods represented by any document(s), or for the good faith or acts and/or omissions, solvency, performance or standing of the consignors, the carriers, the forwarders, the consignees or the insurers of the goods, or any other person whomsoever]. ${ }^{13}$ Bank bukan ahli dalam barang dan perdagangan, karenanya Bank tidak mempunyai pengetahuan yang cukup mendalam untuk menilai kondisi suatu barang termasuk untuk menganalisa syarat dan ketentuan yang diperjanjikan antara importir dan eksportir (perjanjian sales contract). Dengan demikian risiko timbul atas adanya diskrepansi dalam L/C. Diskrepansi tersebut dapat terjadi sebagai akibat dari dokumen yang dipalsukan yang kemudian menyebabkan dampak yang besar terhadap Bank dan Beneficiary. Pasal 15 memuat mengenai pengecualian atas risiko untuk Bank. Namun, Bank dapat pula menjadi bertanggungjawab atas kerugian dan akibat yang terjadi apabila Bank tidak melaksanakan kewajibannya dalam

\footnotetext{
12 Pasal 13 UCP500.

13 Pasal 15 UCP500.
} 
pemeriksaan dokumen dengan alasan yang tidak wajar. ${ }^{14}$ Hal yang perlu diperhatikan adalah bahwa UCP tidak mengatur dengan tegas mengenai persoalan manipulasi dalam transaksi L/C. Manipulasi adalah permasalahan yang terdapat dalam bidang hukum pidana. Kasus penipuan ataupun persekongkolan yang menyebabkan Bank menjadi korban dikategorikan sebagai kejahatan di bidang perbankan dalam sistem hukum Indonesia.

Dalam menjalankan fungsi perbankan, dikenal adanya Prinsip Kerahasiaan Bank (juga dikenal dengan istilah Confidential Principle atau Confidentiality). Pada dasarnya, Prinsip Kerahasiaan Bank ada sebagai upaya perlindungan dan penjaminan hukum bagi para nasabah pengguna jasa perbankan. Bank berfungsi, salah satunya, sebagai pengelola dana nasabah. Diperlukan rasa aman dari pihak nasabah agar kemudian nasabah dapat mempercayakan dan menyerahkan dana atau harta yang dimiliki kepada bank untuk dikelola. Demi memberikan jaminan dan rasa aman bagi nasabah, bank menerapkan Prinsip Kerahasiaan Bank yang, antara lain dilakukan dengan merahasiakan atau tidak menyerahkan kepada pihak lain keterangan-keterangan tentang nasabah dan simpanannya. Namun dengan memperhatikan berbagai risiko yang ada dalam kegiatan perdagangan terutama pada mekanisme L/C, sebagaimana telah dijabarkan sebelumnya, apabila pihak bank yang turut dalam pelaksanaan $\mathrm{L} / \mathrm{C}$ dapat mengetahui terlebih dahulu track record dari pihak-pihak dalam L/C sebelum memberikan keputusan terbit atau tidaknya L/C, maka apabila ada nasabah dengan riwayat perbankan yang buruk, sebagai langkah preventif bank dapat menjadikan track record tersebut sebagai bahan pertimbangan untuk meloloskan L/C atau menolak $\mathrm{L} / \mathrm{C}$.

Atas dasar hal-hal yang telah dipaparkan, Penulis terdorong untuk menyoroti risiko dan tanggungjawab besar yang ditanggung oleh Bank sebagai pihak penjamin risiko dalam L/C. Dalam L/C, Bank, dengan segala keterbatasan pengetahuan dan wawasannya mengenai jual beli barang, hadir pada posisi sebagai "pihak ketiga" yang berada 'di luar' sales contract, namun di saat yang bersamaan Bank harus mematuhi prinsip-prinsip yang ada dalam L/C, secara spesifik dimaksudkan pada prinsip Strict Compliance antara dokumen L/C dan sales contract; yang kemudian diikuti prinsip Pemeriksaan Berdasarkan Dokumen (Examination Based on Documents). Hal ini adalah celah yang harus diwaspadai oleh Bank agar tidak terjebak dalam suatu bentuk tindakan ketidak-hati-hatian dalam menerima dan menerbitkan L/C. Penelitian ini bertujuan untuk mencari cara guna menanggulangi dan mencegah terjadinya penyalahgunaan celah tersebut sehingga dapat menghindarkan Bank dan para pihak yang terkait dalam suatu L/C dari kerugian-kerugian baik secara materiil maupun imateriil, seperti nama baik dan kepercayaan publik dengan menyesuaikan penerapan Prinsip Kerahasiaan Bank.

Penelitian mengenai L/C sebelumnya telah dilakukan pada tahun 2019 oleh Zaned Zihan Sosa Elsera Lubis, M. Nur, dan Sanusi (Para Penulis) dengan judul "Asas Keseimbangan dalam Perjanjian Penerbitan Letter of Credit Sebagai Transaksi Bisnis Internasional" yang diterbitkan dalam Jurnal Magister Hukum Udayana, Volume 8 Nomor 2, Juli 2019. Menurut para penulis, penerapan asas keseimbangan dalam Perjanjian Penerbitan L/C dalam bentuk perjanjian baku belum seimbang, pihak bank

14 Perhatikan bunyi Pasal 13 UCP500 yang menyebutkan bahwa pemeriksaan dokumen harus dilakukan dengan ketentuan 'with reasonable care'. 
penerbit masih memiliki bargaining position yang kuat dalam perjanjian. ${ }^{15}$ Pada tahun 2017 penelitian lain juga telah dilakukan oleh Agus Setiawan dengan judul "Risiko yang Dihadapi Bank dalam Transaksi Pembayaran dengan Letter of Credit (L/C)" yang diterbitkan dalam JIM Bidang Hukum Keperdataan, Volume 1 Nomor 1, Agustus 2017. Penelitian tersebut membahas mengenai risiko yang dialami pihak Bank, terkait pelunasan pembayaran melalui L/C, yang secara spesifik disebabkan karena regulasi di Indonesia yang belum mengatur secara komprehensif tentang L/C ditambah lagi dengan kondisi Indonesia yang belum memiliki peraturan yang dapat mendukung pelaksanaan (compliance) UCP 600 di Indonesia. ${ }^{16}$

Berdasarkan berbagai penelitian yang disebutkan di atas, belum pernah dilakukan penelitian terhadap pengkajian mengenai risiko yang dihadapi Bank karena adanya celah Prinsip Kerahasiaan Bank yang dapat disalahgunakan pada mekanisme pembayaran menggunakan L/C. Dengan berlandaskan keadaan tersebut, artikel ini ditulis dengan harapan dapat memberikan sumbangan baru bagi dunia keilmuan sehingga penting untuk dipublikasikan.

\section{Metode Penelitian}

Metode penelitian yuridis normatif digunakan karena fokus kajian muncul atas norma yang kabur (vague). Digunakan pendekatan perundang-undangan (statute approach) dan analisis norma hukum peraturan perundang-undangan. Teknik studi dokumen digunakan untuk menelusuri bahan hukum, serta analisis kualitatif untuk menganalisis kajian yang ada. Sumber data yang digunakan diperoleh berdasarkan penelitian kepustakaan yang mengkaji dan mengumpulkan berbagai bahan hukum mulai dari bahan hukum primer, sekunder, dan tersier terkait L/C yang berlaku secara internasional terutama dari kepustakaan hukum, UCP, jurnal hukum, dan peraturan perundang-undangan.

\section{Hasil dan Pembahasan}

Issuing Bank bertanggung jawab untuk membayar sejumlah nominal yang tertera dalam tanda terima dokumen dari eksportir (Beneficiary). Umumnya bank yang ditunjuk sebagai Issuing Bank adalah bank yang berlokasi di negara importir. Untuk mencegah terjadinya risiko, dapat juga digunakan peran Negotiating Bank untuk menegosiasikan dokumen yang dikirim ke bank oleh Beneficiary; melakukan verifikasi dokumen dan mengonfirmasi syarat dan ketentuan L/C atas nama Beneficiary untuk mencegah terjadinya diskrepansi. Negotiating Bank akan menerima kemudian memeriksa dokumen penjual untuk memastikan bahwa mereka mematuhi syarat dan ketentuan yang diperlukan dalam L/C. Selanjutnya, Advising Bank akan memeriksa keaslian L/C. Advising Bank bertanggung jawab untuk memberi tahu eksportir bahwa mereka telah menerima persetujuan untuk pembukaan L/C. Advising Bank biasanya

${ }^{15}$ Lubis, Z.Z.S.E., Nur, M., \& Sanusi. (2019). Asas Keseimbangan dalam Perjanjian Penerbitan Letter of Credit Sebagai Transaksi Bisnis Internasional. Jurnal Magister Hukum Udayana, 8(2): 261281. DOI: 10.24843/JMHU.2019.v08.i02.p09, h. 280.

${ }^{16}$ Setiawan, A. (2017). Risiko yang Dihadapi Bank dalam Transaksi Pembayaran dengan Letter of Credit (L/C). Jurnal Ilmiah Mahasiswa Bidang Hukum Keperdataan, 1(1): 13-28. ISSN: 2597-6893 (online), h. 26. 
berlokasi di negara eksportir. Kemudian Confirming Bank akan mengonfirmasi dan menjamin untuk melakukan tanggung jawab pembayaran atau negosiasi penerimaan di bawah ketentuan kredit. Mencermati hal-hal yang telah dijelaskan dalam pendahuluan, dapat dilakukan pengkajian mengenai bagaimana Bank bisa memanfaatkan Prinsip Independensi L/C dan Prinsip Kehati-hatian (Prudential Banking) untuk menghindarkan dirinya dari permasalahan yang merugikan Bank dalam L/C. Prinsip Independensi secara tegas memisahkan perjanjian antara importir dan eksportir (Sales Contract) dengan perjanjian antara importir dan bank (Perjanjian Kredit atau L/C). Bank tidak dapat mengubah atau mengintervensi berbagai kesepakatan yang dibuat oleh eksportir dan importir melalui Sales Contract, namun juga akan kesulitan untuk turut memahami secara penuh isi dari Sales Contract tersebut (dalam kepentingannya untuk menjamin strict compliance). Hal yang dapat dilakukan oleh Bank adalah memaksimalkan kewenangannya sebagai pihak perbankan dalam perjanjian kredit (L/C) dengan importir. Pada posisi ini, Bank dapat melakukan segala hal yang dirasa perlu untuk menjamin terlaksanakannya kewajiban importir terhadap Bank dan kepatuhan terhadap L/C.

Sebagai pembeda, penelitian pada tahun 2019 berjudul "Asas Keseimbangan dalam Perjanjian Penerbitan Letter of Credit Sebagai Transaksi Bisnis Internasional" yang diterbitkan melalui Jurnal Magister Hukum Udayana, Volume 8 Nomor 2, Juli 2019 memiliki limitasi pembahasan pada Asas Keseimbangan L/C sedangkan penelitian ini banyak membahas mengenai Prinsip Independensi dan Prinsip Kepatuhan Ketat. Selanjutnya, penelitian tahun 2017 dengan judul "Risiko yang Dihadapi Bank dalam Transaksi Pembayaran dengan Letter of Credit (L/C)" yang diterbitkan dalam JIM Bidang Hukum Keperdataan, Volume 1 Nomor 1, Agustus 2017 terfokus pada kesesuaian instrumen peraturan nasional dengan ketentuan UCP600 sedangkan penelitian ini merupakan pemunculan gagasan baru sebagai alternatif cara untuk mencegah penyalahgunaan celah dalam prinsip-prinsip L/C, dan tidak membicarakan tentang penyerapan aturan UCP600 dalam regulasi nasional. Atas pertimbangan tersebut, penelitian ini dituliskan supaya dapat memberikan sumbangan untuk dunia keilmuan sehingga penting untuk dicermati.

Dalam kapasitas perbankan, Bank berkegiatan untuk menjalankan sirkulasi keuangan melalui fungsi Funding, Lending, dan Service dengan dua prinsip penting yaitu, Prudential Banking Principle dan Prinsip Kerahasiaan atau Confidentiallity. L/C termasuk dalam produk kredit yang merupakan bagian dari fungsi lending (penyaluran dana). Untuk melakukan pengecekan calon debitur, bank sebagai kreditur terlebih dahulu melakukan pengecekan dengan SLIK. SLIK atau Sistem Layanan Informasi Keuangan merupakan sistem informasi yang pengelolaannya berada di bawah tanggung jawab Otoritas Jasa Keuangan (OJK) yang bertujuan untuk melaksanakan tugas pengawasan dan pelayanan informasi keuangan. Terhadap permohonan kredit, bank harus melaksanakan pemeriksaan 5C yang terdiri dari, (1) Capital, atau pemeriksaan terhadap modal atau kondisi keuangan pemohon kredit; (2) Character, yaitu keberadaan itikad baik pemohon; (3) Collateral, yaitu prospek usaha atau kegiatan yang dimintakan kredit; (4) Capacity, berupa kemampuan atau skill dari pemohon kaitannya dengan kesesuaian kemampuan pemohon untuk mengelola kegiatan atau usaha tersebut dengan baik; dan (5) Condition, terkait dengan stabilitas ekonomi, ada atau tidaknya krisis dan berbagai kemungkinannya di masa mendatang. Tujuan dilakukannya 5C adalah sebagai dasar untuk memperoleh keyakinan bahwa pemohon kredit akan dapat melunasi kredit dengan lancar sesuai dengan yang 
diperjanjikan. Apabila terjadi pelanggaran atau Bank lalai dalam melaksanakan 5C maka akan timbul risiko kredit macet, dan dengan demikian secara otomatis Bank telah melanggar Prinsip Kehati-hatian atau Prudential Banking.

Prudential Banking Principle secara garis besar mensyaratkan "tiada kredit tanpa jaminan," dengan mengingat kembali fungsi Bank sebagai lembaga yang melakukan kegiatan funding, lending, dan service, Bank melakukan sirkulasi atas dana para nasabahnya. Kegiatan tersebut berimplikasi kepada pentingnya reputasi Bank di mata masyarakat untuk dipilih oleh masyarakat sebagai lembaga yang menyimpan dan mengelola dana nasabah yang dipercayakan kepadanya. Jaminan dalam kredit dapat berupa hak tanggungan, tanah dan bangunan, serta kondisi kapabilitas si peminjam yang kemudian dianggap telah tercermin melalui $5 \mathrm{C}$.

Ketaatan terhadap pelaksanaan Prudential Banking yang dilaksanakan dengan baik dapat mengurangi risiko kerugian Bank dalam memberikan kredit salah satunya karena Bank dapat secara langsung dan cepat memeriksa keadaan pemohon kredit, sehingga apabila terjadi kecurigaan terhadap kapabilitas pemohon atau tidak adanya jaminan maka Bank dapat bertindak dengan tepat. Namun kembali lagi, dalam pembahasan mengenai L/C, perjanjian L/C berkaitan dengan kegiatan ekspor-impor yang, dengan demikian, melibatkan pihak-pihak lintas negara. Advising Bank beserta Negotiating Bank atau pun Confirming Bank akan kesulitan, kalau pun tidak mungkin, untuk secara telaten melaksanakan pemeriksaan terhadap pemohon kredit karena bank-bank terkait tidak mengetahui data track record atau rekam jejak dari pemohon kredit. Meskipun diyakini bahwa Issuing Bank semestinya telah melaksanakan Prudential Banking sebelum menerbitkan L/C, namun risiko "pihak ketiga" ini bukan hanya akan menimpa Issuing Bank saja, tapi juga bank terkait lainnya, yaitu Advising Bank, Negotiating Bank, dan Confirming Bank, yang berada jauh dari lokasi importir.

Untuk mengatasi celah tersebut, setiap Bank yang terkait dalam perjanjian L/C perlu mengadakan koordinasi guna berbagi informasi (sharing information) tentang nasabah atau importir tersebut sebagai upaya memperkuat due diligence dan Prudential Banking, serta meningkatkan rasa aman karena Bank yang terkait, meskipun bukan merupakan Bank yang menaungi nasabah (importir) tersebut secara langsung, bisa mendapat keyakinan dari hasil analisanya terhadap kapabilitas Applicant secara berimbang. Meskipun secara kasat mata terlihat "menerobos" Prinsip Kerahasiaan, diperlukan perjanjian antar Bank yang mengatur secara tegas dan rinci bagaimana pelaksanaan sharing information semacam ini untuk dapat tetap mempertahankan rasa kepercayaan nasabah terhadap Bank. Indonesia telah meregulasi tentang hal ini, melalui UndangUndang Nomor 10 Tahun 1998 Tentang Perubahan Atas Undang-Undang Nomor 7 Tahun 1992 Tentang Perbankan (UU Perbankan) dalam pasal 44 yang menyatakan, "Dalam tukar menukar informasi antar bank, Direksi bank dapat memberitahukan keadaan keuangan nasabahnya kepada bank lain." Pasal tersebut dapat dilihat sebagai perwujudan dari perkembangan paradigma perbankan di Indonesia yang dimaksud dalam paragraf ke 5, halaman 2, penjelasan umum. Hal tersebut dilakukan dalam rangka meningkatkan fungsi kontrol sosial terhadap Perbankan, dengan secara lebih khusus menyatakan perlunya dilakukan peninjauan ulang terhadap pembahasan Rahasia Bank yang selama ini cenderung tertutup. Pembahasan tentang Rahasia Bank yang dimaksud adalah bagian yang sangat berpengaruh terhadap kepercayaan masyarakat karena Bank merupakan lembaga yang mengelola dana masyarakat, namun demikian tidak semestinya seluruh aspek yang diusahakan oleh Bank patut 
untuk dirahasiakan secara ketat. ${ }^{17}$ Dengan menggunakan penafsiran luas, pasal tersebut secara lebih lanjut tampak diwujudkan, salah satunya, melalui Peraturan Bank Indonesia Nomor 19/10/PBI/2017 Tentang Penerapan Anti Pencucian Uang dan Pencegahan Pendanaan Terorisme Bagi Penyelenggara Jasa Sistem Pembayaran Selain Bank dan Penyelenggara Kegiatan Usaha Penukaran Valuta Asing Bukan Bank (untuk selanjutnya disebut PBI 19/2017), pasal 56: “Bank Indonesia dapat melakukan koordinasi dan kerja sama dengan pihak dan otoritas lain yang berwenang, baik di dalam maupun di luar negeri," selanjutnya kegiatan koordinasi maupun kerja sama yang dilakukan dapat berupa pertukaran informasi, perumusan ketentuan maupun pedoman, pelaksanaan pengawasan, pendidikan dan pelatihan, sosialisasi, penelitian atau riset, penugasan pegawai, dan/atau, pengembangan sistem informasi. Meski-pun dalam penjelasan pasal 56 ayat (1) disebutkan bahwa koordinasi dan kerja sama yang dimaksud dalam peraturan tersebut dilakukan dalam rangka pencegahan dan pemberantasan tindak pidana pencucian uang dan juga Pendanaan Terorisme ${ }^{18}$, namun Penulis percaya bahwa bila tindak pidana yang dilakukan dengan memanfaatkan celah L/C dianggap sebagai hal yang memiliki urgensi penanganan dan pencegahan (tanpa melupakan bahwa pada prinsipnya tindak pidana secara umum memang merupakan suatu hal yang perlu dicegah) terutama karena hal tersebut dapat merugikan bukan hanya para pihak, namun lebih jauh lagi dapat mempengaruhi hubungan lintas negara, hubungan bisnis, dan nama baik (reputasi) para pihak yang terkait, tidak lupa juga tentang rasa kepercayaan nasabah perbankan maka perluasan limitasi dari pasal tersebut memiliki potensi yang besar untuk dikembangkan guna memunculkan perlindungan yang lebih luas.

\section{Kesimpulan}

Dari analisa yang telah Penulis uraikan di atas dapat diambil kesimpulan bahwa untuk mencegah risiko bagi Bank terkait Strict Compliance dan keterbatasan Bank dalam menilai barang yang diperjual belikan, Bank dapat memaksimalkan kewenangannya melalui Prinsip Kehati-hatian (Prudential Banking) untuk "menerobos" Prinsip Kerahasiaan guna kepentingan sharing information. L/C termasuk dalam produk kredit yang merupakan bagian dari fungsi lending (penyaluran dana). Untuk melakukan pengecekan calon debitur, bank sebagai kreditur terlebih dahulu melakukan pengecekan dengan SLIK yang dikelola oleh OJK untuk melaksanakan tugas pengawasan dan pelayanan informasi keuangan. Terhadap permohonan kredit, bank harus melaksanakan pemeriksaan 5C yang terdiri dari, (1) Capital, (2) Character, (3) Collateral, (4) Capacity, dan (5) Condition. Akibat dari pelanggaran atau kelalaian Bank dalam melaksanakan 5C adalah timbulnya risiko kredit macet, hal ini merupakan indikasi bahwa Bank telah melakukan pelanggaran Prinsip Kehati-hatian atau Prudential Banking. Dengan demikian, Prudential Banking dapat digunakan sebagai landasan dilakukannya koordinasi antara Bank yang terkait dalam perjanjian L/C

17 Penjelasan Atas Undang-Undang Republik Indonesia Nomor 10 Tahun 1998 Tentang Perubahan Atas Undang-Undang Nomor 7 Tahun 1992 Tentang Perbankan (Tambahan Lembaran Negara Nomor 3790).

18 Penjelasan Atas Peraturan Bank Indonesia Nomor 19/10/PBI/2017 Tentang Penerapan Anti Pencucian Uang Dan Pencegahan Pendanaan Terorisme Bagi Penyelenggara Jasa Sistem Pembayaran Selain Bank Dan Penyelenggara Kegiatan Usaha Penukaran Valuta Asing Bukan Bank (Tambahan Lembaran Negara Republik Indonesia Nomor 6121). 
untuk berbagi informasi (sharing information) tentang rekam jejak (track record) keuangan nasabah atau importir, sebagai upaya memperkuat due diligence dan pelaksanaan terhadap Prudential Banking. Instrumen hukum yang dapat dioptimalkan guna melaksanakan mekanisme tersebut, antara lain UU Perbankan dalam pasal 44 serta PBI 19/2017 pasal 56 ayat (1) dan (2).

\section{Daftar Pustaka}

Jurnal

Botosh, H. (2016). Evaluation of The Conditional-Absolute Payment Issue in Letters of Credit: Identifying Which Position Provides Maximum Party Autonomy, Certainty, Flexibility, Fairness and Good Faith. International Journal of Business, Economics and Law, 10(5), 9-14.

Buckley, R. P., \& Gao, X. (2002). The Development of The Fraud Rule in Letter of Credit Law: The Journey So Far and the Road Ahead. University of Pennsylvania Journal of International Law, 23(4), 663-712.

CheHashim, R., \& Mahdzan, N. S. (2014). Fraud in Letter of Credit Transactions: The Experience of Malaysian Bankers. International Journal of Law, Crime and Justice, 42(3), 224-236. https://doi.org/10.1016/j.ijlcj.2014.01.008.

Garcia, R. L. (2010, July-December). The Autonomy Principle of Letters of Credit. Mexican Law Review, 3(1), 67-96. https://doi.org/10.22201/iij.24485306e.2010.5.

Yan, H. \& Xiao, L. (2013). Risk Analysis of Letter of Credit: Based on Principles of 'Independence' and 'Strict Compliance'. International Journal of Business and Social Science, 4(9), 199-209.

Lubis, Z. Z., Nur, M., \& Sanusi, S. (2019). Asas Keseimbangan dalam Perjanjian Penerbitan Letter of Credit Sebagai Transaksi Bisnis Internasional. Jurnal Magister Hukum Udayana, 8(2), 261-281. https://doi.org/10.24843/JMHU.2019.v08.i02.p09.

Mann, R. J. (2000). The Role of Letters of Credit in Payment Transactions. Michigan Law Review, 98(8), 2494-2536. https://doi.org/10.2307/1290352.

Setiawan, A. (2017). Risiko yang Dihadapi Bank dalam Transaksi Pembayaran dengan Letter of Credit (L/C). Jurnal Ilmiah Mahasiswsa Bidang Hukum Keperdataan, 1(1), $13-28$.

$\underline{\text { Disertasi }}$

Zhang, Y. (2011). Approaches to Resolving the International Documentary Letters of Credit Fraud Issue. University of Eastern Finland.

\section{Peraturan Perundang-Undangan}

Peraturan Bank Indonesia Nomor 5/11/PBI/2003 Tentang Pembayaran Transaksi Impor. 23 Juni 2003. Lembaran Negara Republik Indonesia Tahun 2003 Nomor 71 DLN. Jakarta.

Peraturan Bank Indonesia Nomor 19/10/PBI/2017 Tentang Penerapan Anti Pencucian Uang dan Pencegahan Pendanaan Terorisme Bagi Penyelenggara Jasa Sistem Pembayaran Selain Bank dan Penyelenggara Kegiatan Usaha Penukaran Valuta Asing Bukan Bank. Tambahan Lembaran Negara Republik Indonesia Nomor 6121. Jakarta. 
Undang-Undang Republik Indonesia Nomor 10 Tahun 1998 Tentang Perubahan Atas Undang-Undang Nomor 7 Tahun 1992 Tentang Perbankan. Tambahan Lembaran Negara Republik Indonesia Nomor 3790. Jakarta.

Uniform Customs and Practice for Documentary Credits UCP600. 1 Juli 2007. International Chamber of Commerce.

Uniform Customs and Practice for Documentary Credits UCP500. 1993. International Chamber of Commerce. 